\title{
GAMBARAN KETUBAN PECAH DINI DI RSUP PROF DR. R. D. KANDOU MANADO
}

\author{
${ }^{1}$ Joshua G. A. Lowing \\ ${ }^{2}$ Rudy Lengkong \\ ${ }^{3}$ Maya Mewengkang
}

\author{
${ }^{1}$ Kandidat Skripsi Fakultas Kedokteran Universitas Sam Ratulangi Manado \\ ${ }^{2}$ Bagian/SMF Obstetri dan Ginekologi Fakultas Kedokteran Manado \\ Email: joshlowing@yahoo.com
}

\begin{abstract}
Premature rupture of membrane (PROM) is the rupture of fetal membrane before labor. It is assumed that the membrane rupture is related to biochemical changes of the extracellular collagen matrix of amnion and chorion as well as apoptosis of the fetal membrane. This was a descriptive retrospective study. Data were obtained from the medical record of the Department of Obstetrics and Gynecology Department, Prof. Dr. R. D. Kandou Hospital Manado. The results showed that during the period of 1 January - 31 December 2013 there were 3,810 labors; 59 cases (1.54\%) of PROM. Viewed from the position of fetus in utero and the duration of pregnancy, most of the fetus had cephalic presentation and most of the pregnancies were aterm. There was no mortality during the period.
\end{abstract}

Keywords: PROM

\begin{abstract}
Abstrak: Ketuban pecah dini (KPD) merupakan keadaan pecahnya selaput ketuban sebelum persalinan. Pecahnya selaput ketuban diduga berkaitan dengan perubahan proses biokimiawi yang terjadi dalam matriks kolagen ekstrasel amnion dan korion serta apoptosis membran janin. Penelitian ini menggunakan metode retrospektif deskriptif. Data diambil dari rekam medik Bagian Obstetri Ginekologi RSUP. Prof. Dr. R. D. Kandou Manado. Selama periode 1 Januari 2013 - 31 Desember 2013 tercatat 3.810 persalinan dengan 59 kasus KPD (1,54\%). Dilihat dari segi letak janin dan usia kehamilan, sebagian besar janin dengan letak kepala dan usia kehamilan rata-rata aterm. Mortalitas tidak ditemukan.
\end{abstract}

Kata kunci: ketuban pecah dini

Ketuban pecah dini (KPD) atau Premature Rupture of Membrane (PROM) merupakan keadaan pecahnya selaput ketuban sebelum persalinan. Bila KPD terjadi sebelum usia kehamilan 37 minggu, disebut sebagai ketuban pecah dini pada kehamilan prematur atau Preterm Rupture of Membrane (PPROM). Pecahnya selaput ketuban tersebut diduga berkaitan dengan perubahan proses biokimiawi yang terjadi dalam kolagen matriks ekstrasel amnion, korion dan apoptosis membran janin. ${ }^{1}$
Prevalensi KPD berkisar 3-18\% dari seluruh kehamilan. Saat aterm, 8-10\% wanita hamil datang dengan KPD dan 3040\% dari kasus KPD merupakan kehamilan preterm atau hanya sekitar $1,7 \%$ dari seluruh kehamilan. ${ }^{2}$

KPD berpengaruh terhadap kehamilan dan persalinan. Jarak antara pecahnya ketuban dan permulaan persalinan disebut periode laten (lag period $=\mathrm{LP}$ ). Bila periode laten terlalu panjang dan ketuban sudah pecah, maka terjadi infeksi yang 
dapat meningkatkan angka kematian ibu dan anak. ${ }^{3}$

Komplikasi yang paling sering terjadi pada ibu sehubungan dengan KPD ialah terjadinya korioamnionitis dengan atau tanpa sepsis yang meningkatkan morbiditas dan mortalitas perinatal dan menyebabkan infeksi pada ibu dan bayi.. Terjadinya infeksi maternal sehubungan dengan KPD tergantung dari lamanya masa laten, dimana makin muda umur kehamilan makin memanjang periode laten sedangkan persalinan lebih pendek dari biasanya, yaitu pada primi 10 jam dan multi 6 jam. Risiko pada bayi dengan KPD ialah kelahiran prematur dengan segala akibatnya yaitu infeksi, gawat janin, dan persalinan traumatik. Bila masa laten $>24$ jam, maka angka kematian perinatal meningkat dan insiden amnionitis meningkat $>50 \% .^{2,4,5}$

Pengelolaan KPD pada kehamilan $<34$ mingu sangat kompleks dan bertujuan untuk menghilangkan kemungkinan terjadinya prematuritas dan Respiratory Distress Syndrome (RDS). Infeksi neonatal setelah pecah ketuban dipengaruhi oleh kolonisasi kuman Streptokokus Grup Beta, lama ketuban pecah, korioamnionitis, jumlah pemeriksaan vagina, pemberian antibiotika dan lain-lain. ${ }^{2,5,6}$

\section{METODE PENELITIAN}

Metode penelitian ini ialah retrospektif deskriptif dengan menggunakan rekam medik yang berhubungan dengan KPD pada tahun 2013 dan memenuhi kriteria inklusi, yaitu: umur ibu, pekerjaan, paritas, lamanya ketuban pecah, jenis persalinan, dan usia kehamilan.

\section{HASIL PENELITIAN}

Tabel 1. Distribusi Kasus KPD Berdasarkan Umur di RSUP Prof. Dr. R. D. Kandou Tahun 2013

\begin{tabular}{ccc}
\hline $\begin{array}{c}\text { Umur } \\
\text { (tahun) }\end{array}$ & Jumlah & $\mathbf{( \% )}$ \\
\hline$<20$ & 9 & 0,23 \\
$20-24$ & 24 & 0,63 \\
$25-29$ & 12 & 0,32 \\
$30-34$ & 6 & 0,15 \\
$>35$ & 8 & 0,21 \\
Total & 59 & 1,54 \\
\hline
\end{tabular}

Tabel 2. Distribusi Kasus KPD Berdasarkan Paritas di RSUP Prof. Dr. R. D. Kandou Tahun 2013

\begin{tabular}{ccc}
\hline Paritas & Jumlah KPD & $(\%)$ \\
\hline 0 & - & - \\
1 & 32 & 0,84 \\
2 & 27 & 0,70 \\
$>3$ & - & - \\
Total & 59 & 1,54 \\
\hline
\end{tabular}

Tabel 3. Distribusi Kasus KPD Berdasarkan Pekerjaan di RSUP Prof. Dr. R. D. Kandou Tahun 2013

\begin{tabular}{ccc}
\hline Pekerjaan & Jumlah KPD & $(\%)$ \\
\hline IRT/Tidak Bekerja & 48 & 1,26 \\
Pegawai Negeri & 1 & 0,02 \\
PegawaiSwasta & 7 & 0,18 \\
Pelajar & 3 & 0,08 \\
Petani & 0 & 0 \\
Total & 59 & 1,54 \\
\hline
\end{tabular}

Tabel 4. Distribusi Kasus KPD Berdasarkan Lama Ketuban Pecah di RSUP Prof. R. D. Kandou Tahun 2013

\begin{tabular}{cccc}
\hline $\begin{array}{c}\text { Lama } \\
\text { Ketuban } \\
\text { Pecah }\end{array}$ & $\begin{array}{c}\text { Jumlah } \\
\text { Kasus }\end{array}$ & $\begin{array}{c}\text { Jumlah } \\
\text { Seluruh } \\
\text { KPD }\end{array}$ & $\mathbf{( \% )}$ \\
\hline$<12$ & 31 & 59 & 52,54 \\
$12-24$ & 11 & 59 & 18,65 \\
$>24$ & 17 & 59 & 28,81 \\
\hline
\end{tabular}

Tabel 5. Distribusi Kasus KPD Berdasarkan Jenis Persalinan di RSUP Prof. R. D. Kandou Tahun 2013

\begin{tabular}{ccc}
\hline Jenis Persalinan & $\begin{array}{c}\text { Jumlah } \\
\text { KPD }\end{array}$ & $(\%)$ \\
\hline Partus spontan & 53 & 1,39 \\
Seksio Sesarea & 6 & 0,15 \\
Ekstraksi vakum & - & - \\
Total & 59 & 1,54 \\
\hline
\end{tabular}

Tabel 6. Distribusi Kasus KPD Berdasarkan Usia Kehamilan di RSUP Prof. R. D. Kandou Tahun 2013

\begin{tabular}{ccc}
\hline $\begin{array}{c}\text { Usia } \\
\text { Kehamilan } \\
\text { (minggu) }\end{array}$ & $\begin{array}{c}\text { Jumlah } \\
\text { KPD }\end{array}$ & $(\%)$ \\
\hline$<37$ & 16 & 0,41 \\
$>37$ & 43 & 1,13 \\
Total & 59 & 1,54 \\
\hline
\end{tabular}




\section{BAHASAN}

Dari hasil penelitian secara retrospektif periode 1 Januari 2013 - 31 Desember 2013 di bagian Obstetri - Ginekologi BLU RSUP Prof Kandou Manado, ditemukan 59 kasus kasus KPD dari 3.810 persalinan atau $1,51 \%$ dari seluruh persalinan. Kejadian ini lebih kecil dibandingkan dengan hasil penelitian Maharani $^{7}$ yang dilakukan di BLU RSUP Prof. Dr. R. D. Kandou Manado periode 1 Januari 2009 - 31 Desember 2010 dengan 87 kasus KPD.

Kejadian KPD dapat menimbulkan beberapa masalah bagi ibu maupun janin, misalnya pada ibu dapat menyebabkan infeksi puerperalis/masa nifas, dry labour/partus lama, pendarahan post partum, peningkatan morbiditas dan mortalitas maternal, bahkan kematian. Risiko kecacatan dan kematian janin juga tinggi pada kejadian KPD preterm. Hipoplasia paru merupakan komplikasi fatal yang terjadi pada KPD preterm. Kejadiannya mencapai hampir $100 \%$ bila KPD preterm ini terjadi pada usia kehamilan $<23$ minggu. ${ }^{8}$

Semua ibu hamil dengan KPD sebaiknya dievaluasi untuk kemungkinan terjadinya infeksi dan koriamnionitis. Selain itu dapat juga terjadi risiko prolaps tali pusat pada KPD. ${ }^{9}$

Tabel 1 memperlihatkan bahwa kehamilan dengan KPD terbanyak pada kelompok umur 20-24 tahun sejumlah 24 kasus $(0,63 \%)$ dan terendah pada umur 3034 tahun sejumlah 6 kasus (0,15\%). Hasil penelitian ini berbeda dengan yang ditemukan Maharani ${ }^{7}$ dimana kasus KPD terbanyak pada umur 25-29 tahun, yaitu 33 kasus (0,46\%).

Pada Tabel 2 berdasarkan paritas, KPD lebih banyak ditemukan pada primigravida yaitu 32 kasus (0,84\%). Paritas 0 tidak didapatkan KPD. Hasil ini cukup berbeda dengan penelitian Maharani $^{7}$ yang mendapatkan KPD paling banyak ditemukan pada nulipaea sebanyak 52 kasus (0,72\%). Penlitian Maharani dilakukan pada rumah sakit yang sama tetapi menggunakan 2 periode (2009-2010).

Tabel 3 memperlihatkan sebaran KPD terbanyak pada ibu rumah tangga (IRT) yaitu sebanyak 48 kasus (1,26\%), dan terendah pada pekerja sebagai petani, yakni 0 kasus (0\%). Hal ini sama dengan penelitian Maharani di BLU RSUP Prof. Kandou Manado yang mendapatkan KPD terbanyak pada ibu rumah tangga (IRT), yaitu sebanyak 56 kasus (0,78\%).

Pada Tabel 4 berdasarkan lamanya KPD terbanyak didapatkan pada KPD yang berlangsung $<12$ jam yaitu sebesar 31 kasus (52,54\%), sedangkan yang paling sedikit ialah KPD yang berlangsung 12-24 jam yaitu sebanyak 11 kasus (18,65\%). Hasil ini sama dengan penelitian Maharani yang mendapatkan kasus KPD yang berlangsung $<12$ jam sebesar 57 kasus. $^{7}$

Berdasarkan Tabel 5 didapatkan bahwa kejadian dengan letak sungsang sebanyak 6 kasus $(0,15 \%)$ ditolong dengan persalinan sesarea, letak kepala dengan partus spontan yang terbanyak yakni 53 kasus (1,39\%).

Berdasarkan Tabel 6 didapatkan distribusi kasus KPD terbanyak pada usia kehamilan aterm yaitu sebanyak 43 kasus $(1,13 \%)$ dan pada usia kehamilan <37 (preterm) yaitu sebesar 16 kasus (0,41\%).

Persalinan prematur merupakan kelainan proses yang multifaktoral. Kombinasi keadaan obstetrik, sosiodemografi, dan faktor medik mempunyai pengaruh terhadap terjadinya persalinan prematur. Risiko tunggal dijumpai seperti distensi berlebih uterus, ketuban pecah dini, atau trauma. Banyak kasus persalinan prematur sebagai akibat proses patogenik yang merupakan mediator biokimia yang mempunyai dampak terjadinya kontraksi rahim dan perubahan serviks. Pelaksanaan persalinan prematur sering berakibat tokolitik untuk jangka waktu tertentu, sehingga fokus utama harus diarahkan pada hal yang paling penting dan cara kelahiran yang paling tepat untuk hasil terbaik. ${ }^{3,8}$

KPD merupakan faktor utama penyebab infeksi pada kehamilan. Berdasarkan hal tersebut dapat diperkirakan infeksi intauterin akibat KPD dapat menyebabkan kelahiran prematur. Dalam kepustakaan disebutkan bahwa 
usaha untuk menghindari ketuban pecah dini ialah menghindari kerja berat dan hubungan seksual pada bulan-bulan terakhir kehamilan, menjaga kebersihan umum/alat reproduksi karena pecahnya kulit ketuban kadang-kadang didahului cervicitis atau amnionitis. Pencegahan postnatal berupa resusitasi dan perawatan bayi prematur, pemberian nutrisi yang adekuat dan penjelasan pada orang tua penderita tentang perannya dalam mencegah terjadinya gangguan tumbuh kembang pada bayi prematur.,

Untuk mengurangi morbiditas dan mortalitas pada kelahiran prematur diperlukan tindakan resusitasi dengan menggunakan peralatan resusitasi dengan benar pada bayi baru lahir. Pada bayi prematur mempunyai beberapa karakteristik yang menjadi tantangan dalam resusitasi neonatus. Beberapa karakteristik tersebut adalah terdapat kekurangan surfaktan pada paru-paru sehingga menimbulkan kesulitan pada saat membran ventilasi, kulit yang tipis dan kurangya jaringan lemak kulit sehingga memudahkan bayi kehilangan panas, bayi seringkali lahir disertai infeksi serta pembuluh darah otak sangat rapuh sehingga mudah menyebabkan perdarahan pada keadaan stres. ${ }^{10}$

\section{SIMPULAN}

Angka kejadian ketuban pecah dini (KPD) di BLU RSUP Prof. Kandou Manado periode 1 Januari - 31 Desember 2013 sebesar 1,54\%. Dilihat dari segi letak janin dan usia kehamilan, sebagian besar janin dengan letak kepala dan usia kehamilan rata-rata aterm. Mortalitas tidak didapatkan pada penelitian ini.

\section{DAFTAR PUSTAKA}

1. Soewarto S. Ketuban Pecah Dini. In: Winkjosastro $\mathrm{H}$, Saifuddin $\mathrm{AB}$, Rachimhadhi T, editors. Ilmu Kebidanan. Jakarta: Yayasan Bina Pustaka Sarwono Prawirohardjo, 2009.

2. Garite TJ. Prematur Rupture of the Membrans. In: Creasy RK, Resnik R. Iams JD, editors. Maternal-Fetal Medicine Principle and Practice (5th ed.). USA: W.B. Saunders, 2004.

3. Sarwono, P. Ilmu Kebidanan (Edisi 4). Jakarta: Yayasan Bina Pustaka, 2010.

4. Manuaba IBG. Ilmu Kebidanan, Penyakit Kandungan \& Keluarga Berencana untuk Pendidikan Bidan. Jakarta: EGC; 2000.

5. Oxorn H, Forte W. Human Labor and Birth: Patologi dan Fisiologi Persalinan. Yogyakarta: YEM, 2010.

6. Svigos JM, Robinson JS, Vigneswaran R. Premature Rupture of the Membranes. In: James DK, Steer PJ, Weiner CP, Gonik B, editors. High Risk Pregnancy Management Options. London: W.B. Saunders, 1994.

7. Cunningham FG. Obstetri William. Jakarta: EGC, 2006.

8. Liu DTY. Manual Persalinan. Jakarta: EGC, 2008.

9. Maharani S. Gambaran ketuban ppecah dini di BLU RSUP Prof. Dr. R. D. Kandou Manado periode 1 Januari 2009 - 31 Desember 2010 [Skripsi]. Manado: Universitas Dsam Ratulangi, 2011.

10.Manuaba IBG. Pengantar Kuliah Obstetri. Jakarta: EGC, 2007.

11.Yulaikha L. Seri Asuhan Kebidanan Kehamilan. Jakarta: EGC, 2008. 